\title{
Investigation of Immunomodulatory Potential of Whole Plant of Boerhavia erecta Linn.
}

\author{
Vasuki K ${ }^{1 *}$, Murugananthan $\mathrm{G}^{1}$, Banupriya $\mathrm{C}^{2}$, Ramya $\mathrm{R}^{2}$, Mohana priya $\mathrm{C}^{2}$, Shenjudar $\mathrm{D}^{2}$
}

\section{Vasuki $\mathrm{K}^{1 *}$, Murugananthan $\mathrm{G}^{1}$, Banupriya $\mathrm{C}^{2}$, Ramya $\mathrm{R}^{2}$, Mohana priya $\mathrm{C}^{2}$, Shenjudar $\mathrm{D}^{2}$}

'Department of Pharmacognosy, Swamy Vivekanandha College of Pharmacy, Tiruchengode, Tamil Nadu, INDIA. ${ }^{2}$ U.G. Students, Swamy Vivekanandha College of Pharmacy, Tiruchengode, Tamil Nadu, INDIA.

Correspondence

Dr Vasuki K

Swamy Vivekanandha College of Pharmacy, Elayampalayam, Tiruchengode, Tamil Nadu, INDIA.

E-mail: 007vasuki@gmail.com

History

- Submission Date: 24-10-2017;

- Review completed: 31-11-2017;

- Accepted Date: 10-11-2017

DOI : 10.5530/pj.2018.2.42

Article Available online http://www.phcogj.com/v10/i2

\section{Copyright}

(c) 2018 Phcog.Net. This is an openaccess article distributed under the terms of the Creative Commons Attribution 4.0 International license.

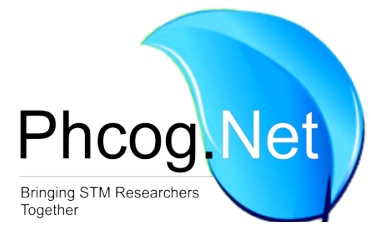

\begin{abstract}
The present study was designed to investigate immunomodulatory activity of aqueous extract of whole plant Boerhavia erecta. The concept of immunomodulation has been gaining much significance worldwide as people started realizing the indispensible role of the immune system in maintaining a disease-free state. Natural products have been considered a plentiful source in the search for new chemical entities that modulate the immune system with reduced adverse effects. Pharmacological evaluation of the crude ethanolic extract of Boerhavia diffusa roots has shown to possess anti proliferative and immunomodulatory properties but not reported from Boerhavia erecta. Due to that, immunomodulatory activity was carried out for the aqueous extract of Boerhavia erecta (Family: Nyctaginaceae). In this present study, aqueous extract of whole plant of Boerhavia erecta exhibited phagocytosis stimulation of human neutrophils against Candida albicans in a dose dependent manner.

Key words: Boerhavia erecta, Candida albicans, Phagocytosis stimulation.
\end{abstract}

\section{INTRODUCTION}

Plant extracts used in traditional therapy are being reviewed for their chemo protective and Immunomodulatory activities. Immunomodulators are biological response modifiers; exert their antitumor effects by improving host defence mechanisms against the tumor. They have a direct anti-proliferative effect on tumour cells and enhance the ability of the host to tolerate damage by toxic chemicals that may be used to destroy cancer.

Immunomodulatory therapy could provide an alternative to conventional chemotherapy for a variety of diseased conditions, especially when host's defence mechanisms have to be activated under the conditions of impaired immune responsiveness or when a selective immunosuppression has to be induced in a situation, like inflammatory diseases, auto-immune disorders and organ/bone marrow transplantation. ${ }^{1} \mathrm{~A}$ number of Indian medicinal plants and various 'Rasayana' have been claimed to possess immunomodulatory activity.

Boerhavia erecta (L.) (Tamil name: Seemai mookarattai) is a weedy herb of the family Nyctaginaceae and is commonly available in almost all places. It is used as a traditional medicinal plant in Africa. ${ }^{2}$ Boerhavia erecta (L.) possess alkaloids, flavonoids, saponins, steroids etc., and more polar compounds like minerals and vitamins. ${ }^{3}$ It has been found to possess diuretic action, ${ }^{4}$ anti-inflammatory, ${ }^{5}$ antifibrinolytic, ${ }^{6}$ anticonvulsant ${ }^{7}$ and hepatoprotective activities ${ }^{8,9}$ antimicrobial activity, ${ }^{3}$ antimalarial activities. ${ }^{10}$

\section{SCIENTIFIC CLASSIFICATION ${ }^{11}$}

Kingdom: Plantae

Clade

: Angiosperms

Order

Family

: Caryophyllales

Tribe

: Nyctaginaceae

Genus

Species

: Boerhavia L.

Binomial name

: erecta

\section{BOTANICAL DESCRIPTION ${ }^{12}$}

Annual to short-lived perennial herb up $1 \mathrm{~m}$ tall, sometimes with a thick taproot; stem branching mainly from the base, ascending to erect, fleshy, green, often flushed with red, lower parts thinly hairy, upper parts glabrous, nodes swollen. Leaves opposite, simple, about equal; stipules absent; base rounded to truncate, apex rounded to acute, margins sinuate, pale green to whitish beneath, sometimes with red marginal glands. Inflorescence an axillary, small, often congested umbel, by reduction of leaves appearing terminal, elongating after start of flowering; bracts and bracteoles small, caducous. Flowers bisexual, regular; pedicel 1-3 $\mathrm{mm}$ long; perianth tubular-campanulate, distinctly constricted halfway, lower part obconical, surrounding the ovary, 5-ribbed, green, upper part 5-lobed, lobes emarginate, white to pale pink or dotted with red, soon falling; stamens 2(3), slightly exserted; ovary superior, seemingly inferior, 1-celled, style slightly exserted, stigma
: Nyctagineae

Cite this article: Vasuki K, Murugananthan G, Banupriya C, Ramya R, Mohana priya C, Shenjudar D. Investigation of Immunomodulatory Potential of Whole Plant of Boerhavia erecta Linn. Pharmacog J. 2018;10(2):241-4. 


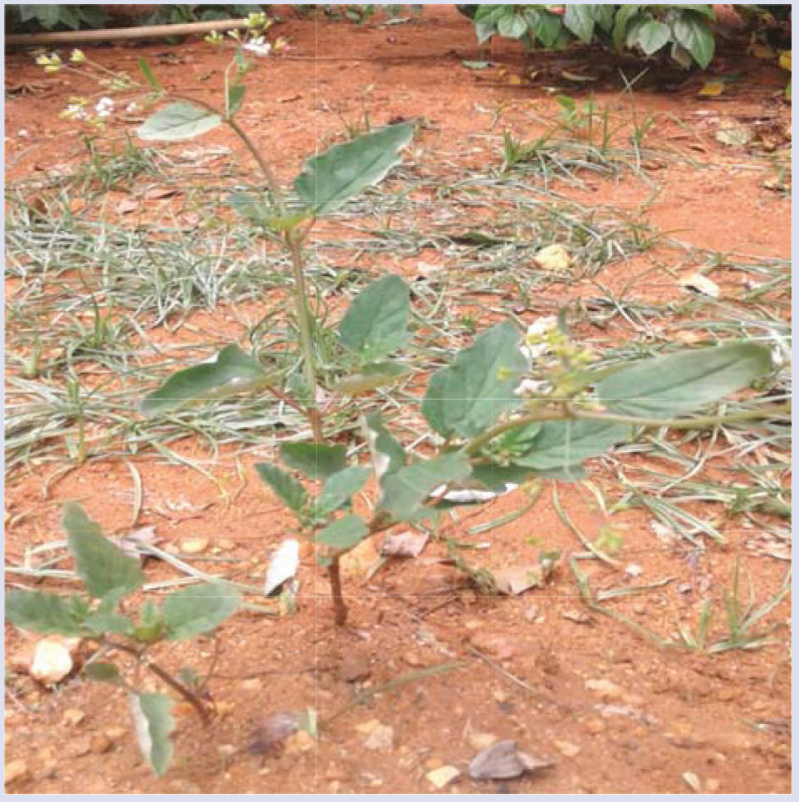

Figure 1: Boerhavia erecta (L.)

head-shaped. Fruit an achene enclosed by the thickened lower part of perianth (collectively called anthocarp); anthocarp obconical or clubshaped, 3-4 $\mathrm{mm} \times 1.5-2 \mathrm{~mm}$ apex truncate, sharply 5-ribbed, with glabrous ribs, 1-seeded. Seed obovoid, pale brown. Seedling with epigeal germination; hypocotyl well developed, shortly hairy; cotyledons rounded, with distinct midvein; first leaves alternate, shortly hairy, purplish beneath Figure 1 .

\section{MATERIALS AND METHODS}

\section{Plant material}

The whole plant of Boerhavia erecta was collected from the outskirts of Tiruchengode, Tamilnadu in the month of March 2017. The plant was then authenticated by the Dr. S. Senthil kumar, Head of the Department of Botany, Vivekanandha College of Arts and Science for Women, Elayampalyam, Tiruchengode. A voucher specimen was submitted at Institute's herbarium department for future reference. The whole plant material was dried in shade and pulverized. The powder was passed through sieve no. 40 and used for the extraction.

\section{Extraction ${ }^{13}$}

In this process, the whole plant of coarsely powdered crude drug was placed in a stoppered container with the distilled water and allowed to stand at room temperature for a period of at least 3 days with frequent agitation until the soluble matter has dissolved. Then, extract was filtered by using muslin cloth followed by Whatman no. 1 filter paper. The extract was subjected for concentration by using vacuum flash evaporator at $90^{\circ} \mathrm{C}$. Finally, the syrupy mass was collected and used for the experiment.

\section{Identification of Phytoconstituents by preliminary phytochemical screening ${ }^{14}$}

The above prepared extract was subjected to qualitative chemical analysis to detect the presence of various phytoconstituents by using standard procedures. The results were tabulated in Table 1.
Table 1: Indicates phytoconstituents present in boerhavia erecta.

\begin{tabular}{ccc}
\hline S.NO. & PHYTOCONSTITUENTS & AQUEOUS EXTRACT \\
\hline 1. & Alkaloids & ++ \\
2. & Saponins & + \\
4. & Carbohydrates & + \\
5. & Tannins and phenolics & ++ \\
6. & Flavonoids & + \\
8. & Fixed oils and fats & - \\
9. & Lignins & + \\
\hline
\end{tabular}

'++' indicates strongly present '+' indicates mildly present '-' indicates negative

\section{In - vitro immunomodulatory screening Method} Phagocytosis of candida albicans assay ${ }^{15}$

Phagocytosis of Candida albicans test was carried out according to method described by Ponkshe and Indap 2002.

\section{Media preparation}

Sabouraud broth was prepared for the present work by dissolving $30.0 \mathrm{~g}$ of Sabouraud broth (containing $10 \mathrm{~g} / \mathrm{L}$ and dextrose 20g/L) (HiMedia) in $500 \mathrm{ml}$ of distilled water. The broth was further sterilized (autoclaved) at $121^{\circ} \mathrm{C}$ for $15 \mathrm{~min}$ at $15 \mathrm{lbs}$ pressure and was used according to the protocol.

\section{Reagents and their preparations}

\begin{tabular}{|c|c|c|}
\hline S.No. & Hank's balanced salt solution & $\begin{array}{c}(\mathrm{g} / 500 \mathrm{ml} \text { of } \\
\text { distilled water) }\end{array}$ \\
\hline & Calcium chloride & $0.70 \mathrm{~g}$ \\
\hline & Potassium chloride & $0.20 \mathrm{~g}$ \\
\hline & Potassium phosphate monobasic (KH $2 \mathrm{PO} 4)$ & $0.03 \mathrm{~g}$ \\
\hline & Magnesium chloride $(\mathrm{MgCl} 2-6 \mathrm{H} 2 \mathrm{O})$ & $0.05 \mathrm{~g}$ \\
\hline & Magnesium sulphate (MgSo 4 -7H $2 \mathrm{O}$ ) & $0.05 \mathrm{~g}$ \\
\hline & Sodium chloride $(\mathrm{NaCl})$ & $4.00 \mathrm{~g}$ \\
\hline & Sodium bicarbonate ( $\mathrm{NaHCO} 3$ ) & $0.075 \mathrm{~g}$ \\
\hline & Sodium phosphate dibasic (Na $2 \mathrm{HPO} 4)$ & $0.024 \mathrm{~g}$ \\
\hline & Glucose & $0.5 \mathrm{mg}$ \\
\hline
\end{tabular}

The solution was sterilized at $121^{\circ} \mathrm{C}$ for $15 \mathrm{~min}$ at $15 \mathrm{lbs}$ pressure and was added with $0.01 \mathrm{~g}$ of phenol red (HiMedia).

\section{Giemsa stain (HiMedia)}

Giemsa stain for the present study was prepared by adding $0.67 \mathrm{ml}$ of Giemsa stain (HiMedia - SO11) in 30ml of distilled water.

\section{Culture preparation}

Sabourauds broth was inoculated with Candida albicans (MTCC 183) and was incubated overnight. The overnight culture of Candida albicans was centrifuged to get the pellet and supernatant was removed. The collected pellet was washed with Hank's balanced salt solution and centrifuged again. This was done for 3-4 times and the final pellets was mixed with a mixture of sterile Hank's balanced salt solution and human serum in proportion $4: 1$. The concentration of $1 \mathrm{X} 10^{8}$ cells was used in present work. 
Table 2: In - Vitro Immunomodulatory Activity of Aqueous Extract of Boerhavia Erecta

\begin{tabular}{ccc}
\hline & \multicolumn{2}{c}{ Phagocytosis stimulation (\%) } \\
\cline { 2 - 3 } Treatment & $5 \mathrm{mg} / \mathrm{mL}$ & $10 \mathrm{mg} / \mathrm{mL}$ \\
\hline Control (PBS) & - & - \\
Aqueous extract of Boerhavia erecta & $73.6 \pm 6.42$ & $96.4 \pm 5.32$ \\
\hline
\end{tabular}

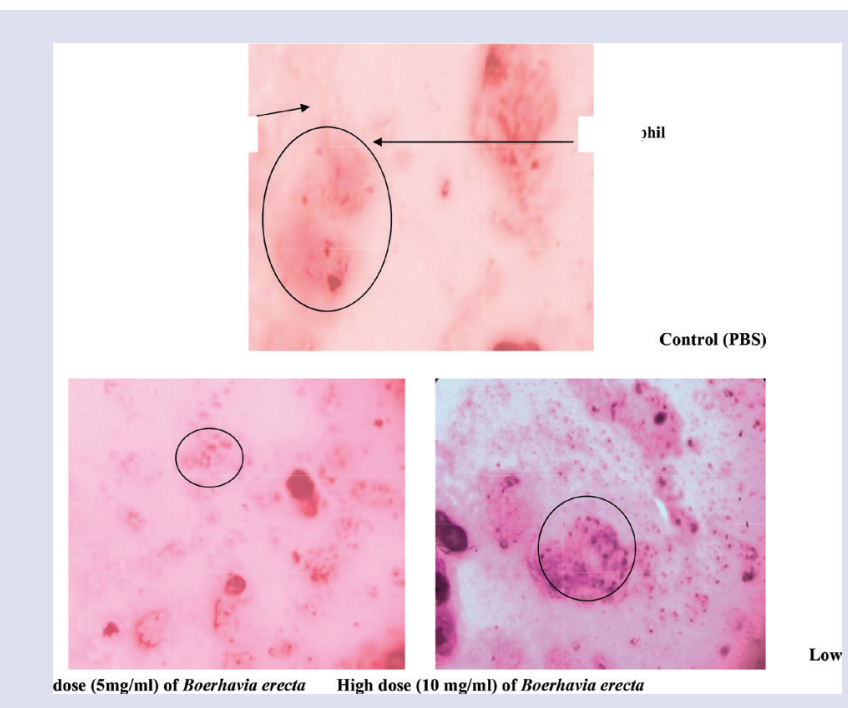

Figure 2: Candida cells, neutrophils, control (PBS), Low dose (5 mg/ $\mathrm{ml}$ ) of Boerhavia erecta High dose $(10 \mathrm{mg} / \mathrm{ml})$ of Boerhavia erecta.

\section{Phagocytosis evaluation}

Briefly, by using finger prick method human blood was added onto the clean glass slide and was incubated at $37^{\circ} \mathrm{C}$ for $25 \mathrm{~min}$ for clotting. Normal sterile saline was further used to remove the clot, in such a way not to wash the adhered neutrophils. $100 \mu$ l of different concentration $(5 \mathrm{mg} / \mathrm{ml}$ and $10 \mathrm{mg} / \mathrm{ml})$ of test plant extract was added on to adhered neutrophils and was incubated at $37^{\circ} \mathrm{C}$ for $15 \mathrm{~min}$. This was followed by addition of predetermined concentration of Candida albicans suspension and incubated at $37^{\circ} \mathrm{C}$ for $1 \mathrm{~h}$. The slides were then drained, fixed using methanol and were stained with Giemsa stain. The number of Candida albicans cells phagocytosed by a human neutrophil on the slide was determined microscopically using morphological criteria. The number of Candida cells phagocytosed/engulfed by a neutrophil was taken as phagocytic index (PI) and the study was performed in triplicates.

\section{Determination of phagocytosis stimulation/ immunostimulation}

Immunostimulation was calculated in percentage using the following equation.

Immunostimulation \% = PI (samples) $/$ PI (control) $\times 100$

Where, PI of samples: Phagocytic index of the test plant extract, PI of control:

Phagocytic index without the test plant extract (i.e. normally by neutrophils). Values were represented in Table 2 and Figure 2 and 3.

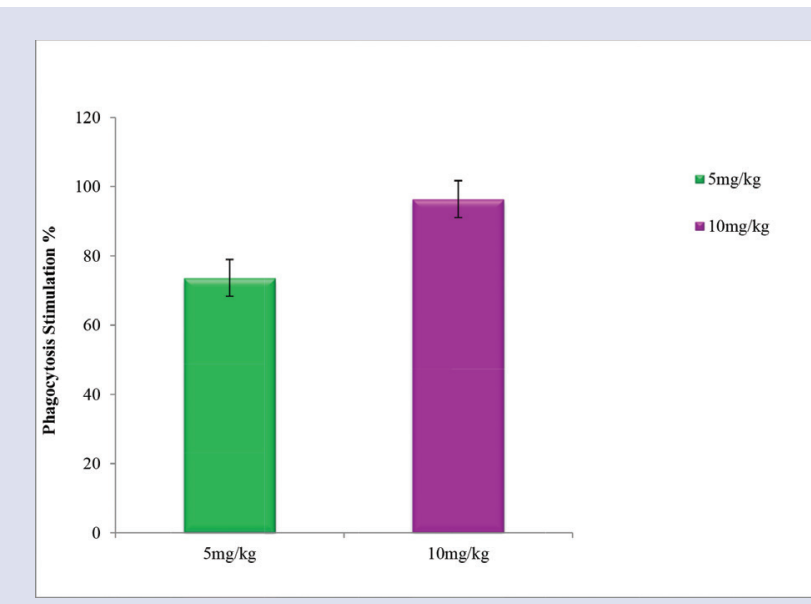

Figure 3: In - vitro immunomodulatory activity of aqueous extract of boerhavia erecta.

\section{Statistical analysis}

Data presented as mean \pm Standard Error Mean (SEM) and were analysed by One-way analysis of variance (ANOVA). The values were considered significantly different at $\mathrm{P}<0.05$.

\section{RESULTS AND DISCUSSION}

The aqueous extract of Boerhavia erecta was preliminarily screened for phytochemical constituents and showed the positive for alkaloids, saponins, tannins, carbohydrates and flavanoids. Immunomodulatory activity (Phagocytosis stimulation) of aqueous extract of Boerhavia erecta showed more significant increase in phagocytosis stimulation percentage $(96.4 \%)$ at $10 \mathrm{mg} / \mathrm{ml}$ compared with $5 \mathrm{mg} / \mathrm{ml}$ (73.6\%). Plant extract showed phagocytosis stimulation of human neutrophils against Candida albicans in dose dependent manner may be due to the presence of alkaloids as per literature.

Synthetic drugs are usually associated with various side effects. More attention is affected by the increasing problems of development of resistance in infectious disease against synthetic drugs. The best alternatives over modern synthetic drugs are plant derived medicine. In this study, aqueous extract possessed significant immunomodulatory activity. The number of Candida albicans cells phagocytosed/engulfed by a human neutrophil on the slide was determined microscopically using morphological criteria.

\section{CONCLUSION}

In conclusion, aqueous extract of Boerhavia erecta showed more significant immunomodulatory (Phagocytosis stimulation). In case of unspecified microbial infection this potent plant extract is much beneficial and nontoxic as compared to the synthetic medicine. It might be concluded that, plant extract possessed phagocytosis stimulatory potential may be due to the presence of alkaloids as per literature. Further isolation and characterisation of phytoconstituents and in-vivo evaluations are undertaken to explore this plant as phytomedicine against pathogenic microorganism.

\section{ACKNOWLEDGEMENT}

The authors are thankful to management, Swamy Vivekanandha College of Pharmacy, Tiruchengode, Tamilnadu, India for providing necessary facilities and support to carry out this research work. 
Vasuki. K et al., Investigation of Immunomodulatory Potential of Whole Plant of Boerhavia erecta Linn.

\section{CONFLICT OF INTEREST}

The author declare no conflict of interest.

\section{ABBREVIATION USED}

MTCC: Microbial Type Culture Collection; SEM: Standard Error Mean; ANOVA: Analysis of variance; PI: Phagocytic Index; PBS: Phosphate Buffered Saline.

\section{REFERENCES}

1. Upadhyay SN. "Plant products as immune response modulators". In Proceedings of the International ayurveda conference, Sanjay Gandhi post graduate institute of medical sciences, Lucknow. 1997;pp.120-7.

2. Florian CS, Dietmar K, Andreas S, Hilou A, Odile GN, Reinhold C, Naturforsch Z. $2004 ; 59 c: 1-8$

3. Suriyavathana M, Parameswari G, Shiyan SP. Biochemical and antimicrobial study of Boerhavia erecta and Chromolaena odorata (L.) King and Probinson. Inter J Pharm Res. 2011;3(2):465-8.

4. Singh RP, Shokala KP, Pandey BL, Singh RG, Usha R Singh. Recent approach in clinical and experimental evaluation of diuretic action of Punarnava (Boerhaavia diffusa) with special effect to nephrotic syndrome. Journal of Indian Medicinal Research. 1992;11:29-36.

5. Bhalla TN, Gupta MB, Bhavgava KP. Anti-inflammatory activity of Boerhaavia diffusa L. Journal of Indian Medicinal Research. 1971;6:11-15.
6. Jain GK, Khanna NM. Punarnavoside: a new antifibrinolytic agent from Boerhaavia diffusa L. Indian Journal of Chemistry. 1989;28:163-6.

7. Mudgal V. Studies on medical properties of Convolvulus Phuricaulis and Boerhaavia diffusa. Planta Medica. 1975;28(5):62-8.

8. Chandan BK, Sharma AK, Anand KK. Boerhaavia diffusa: a study of its hepatoprotective activity. Journal of Ethno pharmacology. 1991;31(3):299-307.

9. Rawat AKS, Mehrotra S, Tripathi SC, Shome U. Hepatoprotective activity of Boerhaavia diffusa L. roots a popular Indian ethnomedicine. Journal of Ethnopharmacology. 1997;56(1):61-6.

10. Hilou A, Nacoulma OG, Guiguemde TR. In vivo antimalarial activities of extracts from Amaranthus spinosus L, Boerhavia erecta L. in mice. J Ethnopharmacology. 2006;103(2):236-40

11. https://en.wikipedia.org/wiki/Boerhavia_erecta

12. Schmelzer GH, Boerhavia erecta L. In: Schmelzer GH, Gurib-Fakim A. (Editors). Prota. 2006;11(1). Medicinal plants/Plantes médicinales 1. [CD-Rom]. PROTA, Wageningen, Netherlands. http://database.prota.org/PROTAhtml/Boerhavia\%20erecta_E n.htm.

13. Sukhdev SH, Suman PSK, Gennaro L, Dev DR. Extraction technologies for medicinal and aromatic plants. International centre for science and high technology. 2008;1:3-4

14. Sharma, Moond, Chouhan, Gupta. Principles of Pharmacognosy, Agrobios India Publishers, Jodhpur. 2008;p.441-2.

15. Ponkshe, Indap. Evaluation of In vitro Immunomodulatory activities of test plant extracts. 2002;82-95.

\section{ABOUT AUTHORS}

Dr. K. Vasuki: Assistant Professor, Department of Pharmacognosy, Swamy Vivekanandha College of Pharmacy, Elayampalayam, Tiruchengode, Namakkal, Tamilnadu, India. She has completed her research work from The Tamilnadu Dr. MGR Medical University. Her area of specialization is natural product exploration. She is life member of Indian Pharmaceutical Association.

Dr. G. Murugananthan: Obtained his M. Pharm. from AlAmeen collge of Pharmacy, Bangalore and Ph.D. degree from PES college of Pharmacy, Bangalore. Currently he is working as Principal at Swamy Vivekanandha College of Pharmacy, Elayampalayam, Tiruchengode, Namakkal, Tamilnadu, India. Murugananthan's research involves novel methods of extraction of botanicals to enhance yield of bioactive compounds and exploration of Medicinal Plants for antidiabetic, anticancer, adaptogenic and antimicrobial activities.

\section{SUMMARY}

- Immunomodulation is the regulation of immune responses by stimulating them to prevent infectious diseases or by suppressing them in the undesired conditions. In the present study we found that Boerhavia erecta Linn. is a potent immunomodulator possessed phagocytosis stimulatory action.

Cite this article: Vasuki K, Murugananthan G, Banupriya C, Ramya R, Mohana priya C, Shenjudar D. Investigation of Immunomodulatory Potential of Whole Plant of Boerhavia erecta Linn. Pharmacog J. 2018;10(2):241-4. 